\title{
Defending Indonesian Boundary from Trans boundary Waste: Implementing Basel Convention on National Level
}

\author{
Clara Ignatia Tobing ${ }^{1}$, Mareta Della $^{2}$, Edwin Sidik Prakoso $^{3}$ \\ \{clara.tobing@ubharajaya.ac.id ${ }^{1}$, della.mareta11@gmail.com² ${ }^{2}$, edwinprakoso73@gmail.com ${ }^{3}$ \} \\ 1,2,3 University of Bhayangkara Jakarta Raya, Bekasi, Indonesia
}

\begin{abstract}
Waste management is one of the environmental threats yet to be solved. The consequences become the waste being diverted to countries in Southeast Asia and Indonesia is one of the concerned countries. Indonesia yet established effective waste management, and as a result, unrecyclable waste is accumulated. Indonesia is dealt with trans boundaries imported waste from developed countries like America, Australia, Canada, and other European countries. The impact of trans boundary waste is an enormous deposit of waste in Indonesia landfill. Transboundary waste is regulated on the Basel Convention on the Transboundary Movement of Hazardous Wastes and their Disposal (the Basel Convention). Nevertheless, due to the limitation of monitoring and observance, institutional coordination among states and inadequate statutory systems to domesticate international statutory obligations, the Basel Convention is inadequate to prevent the threat and public health implications of transboundary waste. The ambiguity of this international structure could threaten Indonesia since most of the transboundary waste was shipped illegally through Indonesian frontier.This writing will examine the danger of transboundary waste to Indonesian security and discuss how the national legislation could improve the prevention regulation.
\end{abstract}

Keywords: Basel Convention, National Security, Transboundary Waste

\section{Introduction}

The problem of waste in Indonesia is one of the problems that yet to be solved over. This has worsened by the habit of disposable plastic products overuse that requires tens to hundreds of years to recycle. Indonesia yet established effective waste management, and as a result, unrecyclable waste is accumulated. Even though the domestic waste problem has yet to be solved, Indonesia is faced with transboundary imported waste from developed countries like America, Australia, Canada, and other European countries.

According to OECD (Organization of Economic Co-operation Development) and other organizations, OECD member countries produce around 300 million tons of hazardous waste annually in the late 1980s, with the United States producing between 260-275 million tons and countries EU member states produce between 20-35 million tons per year. Eastern European countries produce around 19 million tons per year and the remaining produces around 16 million tons. Based on statistical data from the late 1980s and early 1990s, around 10 percent of all hazardous waste is sent across international borders. In Europe, around 2.2 million tons of 
hazardous waste, 100,000 is estimated to send outside European borders. The amount of hazardous waste sent to North America is estimated at 6-9000 tons per year.(Kummer 1995)

Greenpeace estimates that 5.2 million tons of hazardous waste was sent from industrialized countries to Eastern European countries and developing countries between 1986 and 1990. Many of these exports were carried out illegally. Furthermore, Greenpeace estimates the amount of hazardous waste exported from OECD member countries to non-OECD member countries between 1989 and 1994 will amount to 2.6 tons.(Kummer 1995)

The significant problems associated with transboundary waste trade derive from the exportation of hazardous waste from developed countries to developing countries. The industrialized nations confront the dilemma of where to place hazardous waste. The cost of hazardous waste disposal has increased by $100 \%$ in the past twenty years due to developed countries' modern and restrictive environmental laws. Accumulated restrictions have transformed traditional low-cost disposal methods, thereby delivering a reduction in waste disposal ability.(Valin 1994)

The transboundary waste is usually meant to either seek out disposal sites or achieve "resource recovery, recycling, or reuse."(Pratt 2009) Transboundary movement of waste targeted to developing countries, where laws are weak, absent or contravened in the receiving state. Controlled by this waste trade regime, improper waste traders profiteer at the cost of human health and the environment. Corrupt government officials in importing states are induced by enormous financial rewards to accept hazardous shipments of waste.(Onzivu 2013) Unfortunately, many developing countries lack the technology, training, funding, and administrative infrastructure to properly carry out the recycle. Since they lack the capacity to properly handling the waste, it becomes a massive pile of waste. The imported waste results in environmental impact or human exposure. The improper disposal can cause secondary environmental problems, such as harmful smokes or groundwater contamination, which only irritate human exposure concerns and enhance the negative consequences on human health.(Pratt 2009)

As a developing country, Indonesia falls as a victim of such trade. Indonesia was persuaded by the capability of processing plastic waste into economical items like a garbage bag and opportunity to export it as a profitable material. However, the possibilities have been backfiring since plastic recycling industry in disarray and hundreds of containers of used materials clogging its ports. In May 2019, unexpected inspection discovers more than 80 containers of illegal waste from the U.S., Australia, and Europe. About 1,000 containers are currently waiting for inspection at the country's ports; about 600 of them at the Batam port alone.(Singgih 2019)

In June 2019, 5 trash containers from America arrive at the Port of Tanjung Perak, Surabaya. Those were afterward returned to their home country by the Tanjung Perak Customs. 8 containers of paper waste contaminated with B3 waste from Australia also were sent back on July 2019.(Riski 2019) Transboundary waste equally occurs in Batam, where 11 trash containers contaminated with B3 waste arrived.(Arumingtyas 2019) In other hands, TPA (Final Disposal Site) Burangkeng in Bekasi had received transboundary waste from paper factories mixed with plastics as well.(Mantalean 2019)

This waste import problem has an impact on environmental pollution in Indonesia, even though Indonesia itself has not been able to overcome its domestic waste. In addition, Indonesia as a sovereign country should able to firmly prevent and safeguard national borders from waste exporter country that refuses its responsibility.

The ever-increasing amount of imported waste can be both direct and indirect impact on national security. Uncontrollable waste can lead to soil and water pollution, causing environmental degradation. Prompt to deficiency of clean water, natural resources will diminish 
and animals perish. This alone could lead to food scarcity. Food scarcity could be problematic since it can trigger riots and social conflict and/or the illegal harvesting of fish, animals, and plants. Moreover, it has impacts on biophysical and socio-economic consequences of various sources of threat and damage to the environment including pollution, resource degradation, biodiversity loss, and climate change.(White 2014)

Imported waste could become a direct threat to national security since it encompassing territorial inviolability, and economic and political interests that protect the value and stability of the state.(White 2014) As the practice of exporting and importing the hazardous waste consists of several parties, this can induce corruption practice among actors, including the national agencies controlling the transboundary waste trade. Transboundary waste activities should be considered as national security issues that focuses on combating environmental burdens that disproportionately affect minority and poor communities.(Baugh 2015)

\section{Methodology}

This study utilized a qualitative type of research, namely the literature review. First, a preliminary assessment regarding the impact of transboundary waste will be analysed. Second, the authors will observe the model of Basel Convention as the umbrella regulation of transboundary waste, and lastly, the suggestion for Indonesia regulation to reinforce the national security and prevention of transboundary waste will be made.

\section{Results and Discussions}

\subsection{Basel Convention and Transboundary Waste}

According to Basel Convention, transboundary movement means "any movement of hazardous wastes or other wastes from an area under the national jurisdiction of one State to or through an area under the national jurisdiction of another State or to or through an area not under the national jurisdiction of any State, provided at least two States are involved in the movement".(United Nation 1994)

This convention also regulating both hazardous wastes and other wastes such as household wastes and incinerator ash from household wastes, but not radioactive wastes and wastes from ships.(Sundram 1997) It defines wastes as "substances that are disposed of or are intended to be disposed of... by the provision of national law".(United Nation 1994)

The implementation of the Basel Convention promotes the United Nations' mission and work. It provides extra value to a complex and specialized field that no other international body or agreement addresses at the global level. The Parties to the Basel Convention have recognized this shift of emphasis in their 1999 Basel Declaration on Environmentally Sound Management ("Basel Declaration" or "Declaration"). (Portas 2006)

In order for the Convention to be effective, every country needs to develop hazardous waste systems and infrastructures that guard human health and the environment. Through the 2002 Draft Strategic Plan for the Implementation of the Basel Convention, the Parties are carrying out the Basel Declaration. Parties of the convention have re-emphasized the concern of working at the national level, involving municipalities, enriching nongovernmental organizations' onthe-ground experiences, and building partnerships with the private sector. The Basel 
Convention's influence and reach are growing worldwide and expanding regionally.(Portas 2006)

The ground of the Basel Convention itself is to regulating a protection system of the possible harmful effects of transboundary waste on human health and the environment. This is since the export of waste from one country to another considered as harmful to human health and the environment of the recipient country.

This purpose can be seen on article 2 of the convention which stated "Environmentally sound management of hazardous wastes or other wastes" means taking all practicable steps to ensure that hazardous wastes or other wastes are managed in a manner which will protect human health and the environment against the adverse effects which may result from such wastes."(United Nation 1994)

This article can be interpreted the relevant statutory instruments must be based on environmental considerations and that they must, at a minimum, stand by the fundamental principles of the Basel Convention. Particularly, they should establish substantial environmental standards. Article II called for a separate agreement which establishes a regime for the transboundary movement and management of hazardous wastes. It should further the minimization of the generation of hazardous wastes, and their disposal as close as possible to the source of generation.(Kummer 1995)

This also means it should prevent the export of hazardous wastes for the purpose of less environmentally sound by establishing environmental requirements for legal exports. It should acquire a control system for such movements, under which all potentially affected states convey an informed part in the decision on a given transboundary movement. Provision should be prepared for the environmentally sound disposal of the wastes in the event of an illegal transaction, or a transaction that cannot be completed as foreseen. (Kummer 1995)

The interests of developing countries should be taken into consideration as well. Agreements governing waste transactions that involve developing countries should obtain a specific account of the limited capacity of those countries for monitoring the transport and protecting the environmentally effective management of hazardous wastes. This could be completed by imposing stricter mechanisms for the control of hazardous waste transactions than agreements applying exclusively to industrialized countries.(Kummer 1995)

Article 4 requires that "the State of export must guarantee environmentally sound management of the waste and may export waste to a Party State only in situations where it does not have the technical capacity and facilities to dispose of the waste in an environmentally sound manner." The Basel Convention defines "environmentally sound management" as "taking all practicable steps to ensure that hazardous wastes or other wastes are managed in a manner which will protect human health and the environment against the adverse effects which may result from such wastes."(United Nation 1994)

Article 9 of the Basel Convention provides the transboundary movements of hazardous wastes which do not conform to the provisions of the Basel Convention or general principles of international law shall be deemed to be illegal traffic. The Basel Convention provides that "illegal traffic in hazardous wastes is criminal" In determining responsibility for illegal transboundary movement of hazardous waste, the State responsible for the movement of the waste becomes the criminal party. Therefore, it is the criminal party that performs the obligation to ensure the environmentally sound disposal of the hazardous waste by re-importing the wastes or otherwise.(Valin 1994)

The Basel Convention become a mechanism that could be utilized by developing countries to unite against an environmentally harmful trade. This convention compelled industrialized 
countries to accept the instrument for the protection of the environment in more impoverished developing countries. (Sonak, Sonak, and Giriyan 2008)

Why this harmful effect on human health and the environment needs effective regulation? Health and waste are interlinked one and another. The management of waste affects the health of individuals and communities. Aside from the adverse impact, waste management is hard, and most of the waste cannot be easily recycled. This subsequently will affect the environment and disrupts the health of humans and other living things. For example, plastic waste polluted the soil could impact the abiotic and biotic ecosystem. In addition to polluting the soil, it can also pollute the water where the garbage floats in the water then can be eaten by the animals. The consumption of waste exposes animal can lead to dangerous diseases.(Okunola A et al. 2019)

According to WHO, Inadequately waste disposal of untreated waste may cause severe health problems for populations surrounding the area of disposal. Leaks from the waste may contaminate soils and water streams, and produce air pollution through emissions and persistent organic pollutants, ultimately creating health hazards. (WHO Regional Office for Europe 2016)

Moreover, the surrounding community that lives close to the landfill is exceptionally vulnerable to contamination generated from the existing pile of garbage. It is also very threatening for the health and development of children, and pregnant women and their foetuses.(Saffron, Giusti, and Pheby 2003) Health and waste are interlinked one and another. The management of waste affects the health of individuals and communities.(Onzivu 2013) Managing waste properly and in an environmentally sound way is therefore important for health reasons. Despite the increasing recycling activities, landfills and incinerators are widely used to manage the terminal phase of waste disposal. (WHO Regional Office for Europe 2016)

\subsection{The Shifting Trend of Global Transboundary Waste}

The prominent producer of global waste inevitably come from developed countries, since the development process which involves heavy industrialization to achieve capitalistic economic progress. The global amount of hazardous waste in 1945 was estimated to a total of five million metric tons. It had increased to an estimated four-hundred million metric tons in 2000. Three-fourths of this amount is estimated to be generated in industrialized, developed nations.(Pratt 2009)

A significant number of the wastes were export to the developing world generally for economic reasons. Rigid environmental regulations have increased the cost of waste disposal in industrialized nations with the result that richer countries move these hazardous wastes to the most developing nations. Prior to the awareness of environmental protection, those states have accepted the waste even with its detrimental side effects for human health and the environment.(Ajibo 2016)

Contrary to popular belief, harmful waste does possess an economic value. Transferring harmful wastes do not only eliminate the dangers caused by harmful wastes locally but also saves a great deal of money and fosters international trade interests. Then again, in developing countries, imported waste not only brings in a large amount of money but provides employment opportunities, both of which help to stimulate economic growth too.(Tou 2008)

This economic pressure constrained the developing countries to accept the waste. Developed countries predominantly contain increasingly rigid environmental regulations governing the domestic disposal of hazardous wastes. When compliance costs are coupled with an accumulated quantity of waste and local opposition to disposal, they generally generate drastically increased disposal costs for hazardous waste. In comparison, developing countries lack both the rigid regulations and enforcement strategies of the developed world, causing an 
enormous gap in the costs of disposal. Inexpensive land and labour for landfill operations in these developing countries make hazardous waste exports a cost-effective option for hazardous waste producers in developed countries.(Pratt 2009)

UN Environment and the Secretariat of the Basel Convention reported a significant number of increasing case of transboundary waste. An increase from 9.3 to 14.4 million tonnes in transboundary movements of household wastes was recorded between 2007 and 2015. In the year 2015, the lower-middle-income and the higher-middle income countries were responsible for the increase in the generation of hazardous waste, with a range from 256-259 tonnes in 2007 to 390-394 tonnes in 2015. The upper-middle-income countries also contributed to the increase of generated household waste by approximately $12 \%$.(Hecht and Werbeck 2018)

African countries have long become a victim of such activities. The Koko incident in Nigeria in 1987 happened when toxic wastes were dumped in Koko due to an agreement between a Nigerian citizen and an Italian waste trader. The Nigerian was unaware of the content of the substance when he executed the contract with the disposal of hazardous wastes. Directly after the disposal, the toxic waste produced harmful effects. In 1988 the Nigerian government called for the Italian government to take back the hazardous wastes.(Kanamugire 2017)

Another notorious environmental disaster due to the transboundary waste is Probo Koala Disaster. In August 2006, an Ivorian company accepted over five hundred tons of toxic sludge previously denied disposal in Europe, transported it into trucks and placed it in several local locations on the city of Abidjan. The waste arrived in the Probo Koala, a ship possessed by a Greek shipping company, flying a Panamanian flag and leased by the London branch of Trafigura headquartered in The Netherlands. This sludge fatally poisoning ten people and led over 100,000 others to seek medical treatment. Trafigura's deliberate non-disclosure of the quantity and hazardous nature of the waste and its impact on health led to the rejection of the Amsterdam Port Services to dispose of the waste.(Onzivu 2013)

The same accident happened in Seveso Drums incident. On 10 July 1976 the safety valve of a reactor used in a chemical plant run in Meda, Italy burst. As a result, a cloud containing the extremely toxic substance polluted an area of 1,807 hectares. After further investigation, on 10 September 1982, 41 drums containing soil polluted by the Seveso dioxin had crossed the border between Italy and France at Ventimiglia. Allegedly, the customs officers did not realize the drums indeed contained the dioxin of the Seveso incident.(Scovazzi 2001)

The recent development of environmental protection awareness has developed developing countries knowledge on the harmful effect of imported waste. Currently, the impacted country relatively fast to acknowledge the damage of such waste, and the rejection made rapidly.

The shifting global trend probably happened since China started to band imported waste. Before 2017, China accepted imported waste as a mutually beneficial arrangement. The imported waste was needed because it was frequently of more superior quality than what was available domestically, and developed countries found that it was cheaper to discharge the waste abroad than to recycle it alone.(Mak 2018) Until 2017, China had been received $56 \%$ of the world's plastic garbage to recycle, along with a significant portion of its paper refuse, $60 \%$ from the United States, and more than $70 \%$ from Europe. (Schauenberg 2019)

This leads to a threat, both to the environment and human health in China. For example, In Guiyu, China, imported e-waste has caused significant problems for the local environment and community health since the 1990s. The waste caused toxic concentration on local atmosphere, and soil was severely contaminated due to informal e-waste recycling activities. Processing waste plastics has significantly contributed to the accumulation of organic pollutants in this region too.(Tan, $\mathrm{Li}$, and Boljkovac 2018) 
China started to ban the transboundary waste by enacting the Prohibition of Foreign Garbage Imports: the Reform Plan on Solid Waste Import Management in April 2017. This complete ban on the import of four classes of wastes was taking measure by the end of 2017, including waste plastics from household garbage, unsorted waste paper, waste textile materials, and vanadium slag. In addition, it contained further requirements to end the import of solid wastes that can be replaced by China's domestic supply with equivalent wastes by the end of 2019.(Tan, Li, and Boljkovac 2018)

The global result of this ban has changed international waste flows and the migration of the waste processing industry. As a result, the waste will be disposed of or recycled in the country where it is generated, while the rest will be exported to other developing countries.(Tan, Li, and Boljkovac 2018)

In 2019, Malaysia received unrecycled plastic waste from the United States, Canada, the United Kingdom, and Australia. 3300 tons of plastic waste was sooner remitted to their home countries in an effort to prevent Malaysia to become a landfill for developed countries. Malaysia and other developing countries already became a recent destination for importing waste after China restricted certain types of waste. Among those pile, 60 plastic waste containers had been contaminated. The waste reportedly smuggled from a trip to an illegal processing facility.(CNBC 2019)

The similar problem then occurred in the Philippines, where waste from Canada has existed since 2013 and 2014 in two ports in the Philippines while Canada refuses to acknowledge the problem. Eventually, in May 2019 the Philippines government sent 69 containers of garbage back to its home country.(Petersen 2019)

The aftermath of China Ban also caused a hazardous waste ban on Vietnam. The rocketing amount of imported waste has become a threat to Vietnam environment and required significant measure. The regulation waste made to prevent waste from entering Vietnam and transformed the country from becoming a dumping site, affecting the environment and people's lives. (Staub 2018)

\subsection{Transboundary Waste in Indonesia Frontier}

Due to the China policy to reduce its import of global plastic and paper waste, the number of imported wastes in Indonesia gradually increasing since 2017. Indonesia's waste imports rapidly soared from 10,000 tons per month in late-2017 to 35,000 tons per month in late-2018. The primary partners were Germany at 10,000 tons per month, Australia at 6,000 tons per month, Netherlands, USA and UK at 4,000 tons per month.(Greenpeace 2019)

Consequently, Indonesia becomes absolutely potential to become world's largest dumpster. Statistic Agency data stated, in 2018, Indonesia's waste import increases 141 percent or 283,152 tons, with export number is 98,450 tons or 48 percent. These import wastes also sold to local residents for Rp1 million (US\$70.60) per truck which can be resold for up tp Rp2 million (US\$141.20). Simultaneously, non-recyclable plastic scrapes can be resold as fuel for local tofu factories. Residues from imported plastic and paper frequently dumped into Brantas river or burn. The result is water and air pollution. Currently, the river is the resource for six million people in Surabaya City.(Purningsih 2019) This absolutely concerned since it means a disease breakout could happen anytime because of the massive deposit of waste accumulated in the water.

The statutory framework for the environmental management in Indonesia lies on Indonesia's Law No. 32 of 2009 on the Protection and Management of the Living Environment. Hazardous waste management is further elaborated within the framework with the government 
regulations. The previous revision of the regulation is currently stipulated under Government Regulation No. 101 of 2014 on Management of Toxic and Hazardous Waste Substances (GR No. 101/2014).

One complex transboundary waste in Indonesia is plastic. Since plastic harder to recycle, most developed countries choose to export its plastic scrap to developing countries, including Indonesia. The imported plastic waste comes mixed in with paper and cardboard recycling. Ecoton estimates that as much as $60-70 \%$ of the imported paper recycling is contaminated with plastic waste.(GAIA 2019)

The impact of the imported waste is an enormous deposit of waste in Indonesia landfill. BPS (Badan Pusat Statistik) on 2018 recorded 283 tons of imported plastic scrap around, which make it the most excessive amount in the last 10 years. (ICEL 2019) Regrettably, not all of the imported waste can be recycled. This is because of the rules of importing waste regulated in Permendagri No. 31 of 2016 since it contains hazardous and toxic ingredients.

The plastic was discarded with a fraud scheme to Indonesian villages. In Sumengko, Gresik, Indonesia, the entire village was unaware of the hazardous effect of the imported waste. The waste mafia would dump the pile into the soil of the village with an exchange of goods hide in the trash. The paper companies separate, wash and strip the plastic, load it into trucks and dump it in surrounding villages, where middlemen discover communities of low-wage willing workers to sift through the plastic waste. The mafia informs them that the plastic waste dumped into their cassava fields or on their front yards turn to an opportunity for them, a terrific job. In exchange for sifting out the last bits of recyclable plastic and metal from trash, they can obtain whatever they discover. Their only payment is in whatever treasure they can find in the trash.(GAIA 2019)

Sumengko villagers do not aware of the proper waste management center to deal with the rest of the waste. Instead of reuse or recycling, they preferred incinerating the waste. The burnt waste then emits chemical fumes that dangerous to human health. In addition, the burned plastic chemical will pollute the village soil and poison their crops. Although the direct impact on the villagers' health yet to be seen, some babies in the village reportedly caught some coughs.(GAIA 2019)

Dusunangun in East Java also has become a place for separating plastic waste for more than 15 years. However, since 2018, arrived pile comes from imported waste. This evidently showed from the unfamiliar brand of plastic waste to the local community. The waste pile has caused several detrimental effects, like contaminated water and pungent odor. The contaminated water also caused miscarriage to a local villager.(GAIA 2019)

Aside from conventional plastic and paper waste, Indonesia also flooded with electrical and electronic waste (e-waste). In 2012, document adulteration occurred in the Port Tanjung Priok. Tanjung Priok Custom suspected the arrival of 113 containers that inconsistent with the document bill of lading. Afterward, they found the containers consisted of e-wastes like PCB (Print Circuit Board), asphalt, chemicals packaging, and garbage. (Priyono 2017)

Illegal e-waste trade in Indonesia also consistently carried out to several Batam ports. The waste was concealed as raw material, reconditioning/re-use, charity and disposal. Batam was subject to this illegal trade since the city also hides unofficially port entry. The short distance between Batam and Singapore affects the e-waste smuggling and it is lack of control by the central government.(Priyono 2017)

The processing techniques for e-waste by the informal sector are generally as simple as by being melted (heated), burned, or extracted in very acidic solutions. The improper management could lead to various uncertain elements or compounds are released or discharged into the environment without control. From the process of burning cable to obtain copper metal, for example, smoke containing dioxin or polychlorinated dibenzo-p-dioxin could emit. Various 
cases due to heavy metals or toxic compounds from electronic waste recycling have emerged in several areas in Indonesia.(Wahyono 2018)

The detrimental effect of toxic from e-waste relatively release faster to the environment and show pronounced diseased to human health. E-Waste contamination in Munjul, East Jakarta was causing skin disease and respiratory diseases in the surrounding population. On 2009-2010 40 in Tangerang, Bogor dan Tegal, 40 children were found to be exposed to lead content in their blood which exceeds the WHO allowable threshold.(Wahyono 2018)

\subsection{Suggestion and Regulation Model}

After observing several problems arise against transboundary waste that enters Indonesian sovereignty, authors will highlight the need for substantial environmental protection. On this paper, we suggest the government should form laws governing the export and import of waste. This should act as a stringent measure of opposing the existence of waste export. As a developing country, numerous people still unaware of the importance of a healthful environment. On developed countries, the awareness of the harmful effects of waste is generally socialized. In contrast, as a developing country, Indonesia yet establishes effective regulation on law enforcement. In addition, Indonesia, however, lacks management facilities for waste and non-destructive and hazardous waste management.

As developing countries, the shortcoming of Indonesia waste management system could also describe as follow:(Tou 2008)

The management system is not complete, the personnel quality is not high, and the management level is limited in power and scope.

The disposal technologies, equipments and facilities are backward.

The harmful wastes exchange system is flawed.

The phenomenon of operating harmful wastes without licenses is relatively common, which subsequently resulting in greater secondary latent pollution.

The stringent regulation should, in addition, contain responsibilities clause that should fall to the developed countries. State responsibilities means "When a subject of international law violates the act or omission of international law and causes damages to other subjects, the subject of international law bares the responsibility for damage compensation. This kind of damage liability regime is called international responsibility in international law."(Tou 2008)

This responsibility arises not solely because of the damage that occurred but also when a country has not caused damage but there is a possibility of damage. Generally, few actions that cause material damage to its illegality, but rather an illegal violation of the subject of international law or material of political rights.(Tou 2008)

The responsibility for damage resulting from transboundary movements of hazardous waste also has the same meaning as state responsibility since both of them aim at determining international responsibility that must be taken by States as a consequence of the responsibility of the actions they take.(Tou 2008)

The scope of the responsibility and liability on the transboundary waste are:(Tou 2008)

Only subjects of international law can be liable for damages from transboundary movements of harmful wastes. These include States, international organizations and domestic enterprises that are involved in the transboundary movement of harmful wastes.

The liability arises from the transboundary movements of harmful wastes.

The liability is a type of responsibility at the international level.

In terms of responsibility, the absence of rules regarding transboundary waste proves weak law enforcement in Indonesia. Indonesia should have made laws regarding the provisions on the 
export and import of B3 and non-B3 waste. The Permendagri as existing law would not suffice as it is not powerful enough to enforce the principle of protection in the national and international level.

This writing suggests a national regulation concerning the hazardous transboundary waste should govern:

Those who can carry out export and import activities of waste should obtain licenses or permits from the Ministry of Environment. This permit is to ensure the imported waste will not harm and damage nature, the environment and health;

Those who can export should obtain official documents/permits from the country of origin to enter Indonesian territory if they involve such waste;

Classification of imported waste. In this manner, it should not contain and is uncontaminated with hazardous compounds that can have a negative impact on the environment and living things.

The importer company should establish an environmentally friendly waste management system.

Impose severe sanctions for waste importing countries, organizations, and companies if they failed to meet the requirements, and carry out sanctions in the form of:

5 years prohibition of exporting waste;

Fines and Compensation along with a 5 years export ban.

Sanctions for importers:

Revocation of license and / or license suspension;

Fines and compensation for environmental damage due to the absence and or poor waste management system.

\section{Conclusions}

The practice of importing and exporting waste that is regulated in Minister of Trade Regulation No. 31 of 2016 is in adequate. As the consequences, developed countries still deceiving the smuggling B of hazardous waste into containers exported to Indonesia. This has led to a negative impact on the environment and public health since it certainly detrimental to Indonesia. The violation happened mainly due to the flawed structure of law enforcement. Indonesia is, up until now lack of transboundary hazardous waste management regulation. To prevent the detrimental effect and conserving the environment, Indonesia should establish an internationally recognized official umbrella regulation to strengthen law enforcement and tighten the practice of transboundary hazardous waste into Indonesia.

\section{References}

[1] Ajibo, Kenneth I. 2016. "Transboundary Hazardous Wastes and Environmental Justice: Implications for Economically Developing Countries." Environmental Law Review 18 (4): 267-83. doi:10.1177/1461452916675538.

[2] Arumingtyas, Lusia. 2019. "Setelah Surabaya, Pemerintah Akan Kembalikan Sampah Di Batam Ke Negara Asal." Mongabay.Co.Id. https://www.mongabay.co.id/2019/06/17/setelah-surabayapemerintah-akan-kembalikan-sampah-di-batam-ke-negara-asal/.

[3] Baugh, Mccall. 2015. "An Unfulfilled Promise: How National Security Deference Erodes Environmental Justice.” Golden Gate University Environmental Law Journal 8 (1). 
[4] CNBC. 2019. "Malaysia to Send Back Plastic Waste to Foreign Nations." CNCB.Com. Malaysia to send back plastic waste to foreign nations.

[5] GAIA. 2019. "Discarded: Communities on the Frontlines of the Global Plastic Crisis." https://wastetradestories.org/wp-content/uploads/2019/04/Discarded-Report-April-22.pdf.

[6] Greenpeace. 2019. "Data from the Global Plastics Waste Trade 2016-2018 and the Offshore Impact of China , s Foreign Waste Import Ban." http://www.greenpeace.org/eastasia/Global/eastasia/publications/campaigns/toxics/GPEA Plastic waste trade - research briefing-v1.pdf.

[7] Hecht, Dieter, and Nicola Werbeck. 2018. "Waste Without Frontiers II." Basel Convention and UN Environment. Vol. 33. doi:10.1007/BF02926821.

[8] ICEL. 2019. "Meski Dilarang, Impor Sampah Plastik 2018 Naik 141\%." Icel.or.Id. https://icel.or.id/meski-dilarang-impor-sampah-plastik-2018-naik-141/.

[9] Kanamugire, Jean. 2017. "African Response to Transboundary Movement of Hazardous Wastes." Acta Universitatis Danubius Juridica 3.

[10] Kummer, Kathrina. 1995. International Management of Hazardous Waste: The Basel Convention and Related Legal Rules. New York: Clarendon Press.

[11] Mak, Aaron. 2018. "Why Does Half of the World's Used Plastic End Up in China." Slate.Com. https://slate.com/technology/2018/06/why-china-import-half-world-used-plastic.html.

[12] Mantalean, Vitorio. 2019. "5 Fakta Tentang Sampah Dari Luar Negeri Di Burangkeng, Bekasi." Kompas.Com. https://megapolitan.kompas.com/read/2019/08/01/05520071/5-fakta-tentang-sampahdari-luar-negeri-di-burangkeng-bekasi?page=all.

[13] Okunola A, Alabi, Ologbonjaye Kehinde I, Awosolu Oluwaseun, and Alalade Olufiropo E. 2019. "Public and Environmental Health Effects of Plastic Wastes Disposal: A Review." Journal of Toxicology and Risk Assessment 5 (2). doi:10.23937/2572-4061.1510021.

[14] Onzivu, William. 2013. "(Re)Invigorating the Health Protection Objective of the Basel Convention on Transboundary Movement of Hazardous Wastes and Their Disposal." Legal Studies 33 (4): 621-49. doi:10.1111/lest.12000.

[15] Petersen, Hannah Ellis. 2019. "Philippines Ships 69 Containers of Rubbish Back To." The Guardian.

[16] Portas, Pierre. 2006. "The Basel Convention, Back to the Future." Sustainable Development Law \& Policy 3 (6).

[17] Pratt, Laura A. 2009. "Decreasing Dirty Dumping? A Reevaluation of Toxic Waste Colonialism and the Global Management of Transboundary Hazardous Waste." William and Mary Environmental Law \& Policy Review 35 (2): 581-623. doi:10.2298/JMMB121013038C.

[18] Priyono, FX.Joko. 2017. "Law Enforcement of Electrical and Electronic Waste Smuggling in Batam, Indonesia." Diponegoro Law Review 2 (1): 40. doi:10.14710/dilrev.2.1.2017.40-56.

[19] Purningsih, Dewi. 2019. "Indonesia Potentially Becomes World's Largest Plastic Waste Importer." Greener.Com. https://www.greeners.co/english/indonesia-potentially-becomes-worldslargest-plastic-waste-importer/.

[20] Riski, Petrus. 2019. "Aktivis Lingkungan Jatim Tuntut Pemerintah Reekspor Sampah Impor, Tegakkan Aturan." VOA Indonesia. https://www.voaindonesia.com/a/aktivis-lingkungan-jatim-tuntutpemerintah-reekspor-sampah-impor-tegakkan-aturan/4995714.html.

[21] Saffron, Lisa, Lorenzo Giusti, and Derek Pheby. 2003. "The Human Health Impact of Waste Management Practices: A Review of the Literature and an Evaluation of the Evidence." Management of Environmental Quality: An International Journal 14 (2): 191-213. doi:10.1108/14777830310470422.

[22] Schauenberg, Tim. 2019. "After China's Import Ban, Where to with the World's Waste?" DW.Com. https://www.dw.com/en/after-chinas-import-ban-where-to-with-the-worlds-waste/a48213871.

[23] Scovazzi, Tullio. 2001. "The Transboundary Movement of Hazardous Waste in the Mediterranean Regional Context." UCLA Journal of Environmental Law and Policy 19 (1). 
[24] Singgih, Viriya. 2019. "Plastic Waste Piles Up as Indonesia's Import Crackdown Backfires." Bloomberg.Com. https://www.bloomberg.com/news/articles/2019-08-01/plastic-waste-piles-up-asindonesia-s-import-crackdown-backfires.

[25] Sonak, Sangeeta, Mahesh Sonak, and Asha Giriyan. 2008. "Shipping Hazardous Waste: Implications for Economically Developing Countries." International Environmental Agreements: Politics, Law and Economics 8 (2): 143-59. doi:10.1007/s10784-008-9069-3.

[26] Staub, Colin. 2018. "Container Backlogs Cause More Import Strife in SE Asia." Plastic Recycling Update. https://resource-recycling.com/plastics/2018/08/01/container-backlogs-causemore-import-strife-in-se-asia/.

[27] Sundram, Muthu S. 1997. "Basel Convention on Transboundary Movement of Hazardous Wastes: Total Ban Amendment.” Pace International Law Review 9 (1).

[28] Tan, Quanyin, Jinhui Li, and Craig Boljkovac. 2018. "Responding to China's Waste Import Ban through a New, Innovative, Cooperative Mechanism." News. Environmental Science and Technology 52 (14). American Chemical Society: 7595-97. doi:10.1021/acs.est.8b01852.

[29] Tou, Xiaodong. 2008. "The Transboundary Movement of Harmful Wastes and the Transformation of Traditional State Responsibility." Macquarie Journal of International and Comparative Environmental Law 5 (1).

[30] United Nation. 1994. Basel Convention - Transboundary Movements of Hazardous Wastes and Their Disposal. http://www.ncbi.nlm.nih.gov/pubmed/7697032.

[31] Valin, Donna. 1994. "The Basel Convention on the Control of Transboundary Movements of Hazardous Waste and Their Disposal: Should the United States Ratify the Accord?" Indiana International \& Comparative Law Review 6 (1).

[32] Wahyono, Sri. 2018. "Kebijakan Pengelolaan Limbah Elektronik Dalam Lingkup Global Dan Lokal.” Jurnal Teknik Lingkungan 14 (1): 17-24.

[33] White, Rob. 2014. "Environmental Insecurity and Fortress Mentality." International Affairs 90 (4): 835-51. doi:10.1111/1468-2346.12143.

[34] WHO Regional Office for Europe. 2016. "Waste and Human Health: Evidence and Needs." http://www.euro.who.int/_data/assets/pdf_file/0003/317226/Waste-human-health-Evidence-needsmtg-report.pdf?ua=1. 